\title{
Grazing preference for pasture species by sheep is affected by endophyte and nitrogen fertility
}

G.R. EDWARDS*, R.J. LUCAS and M.R. JOHNSON

Plant Science Department, PO Box 84, Lincoln University, Canterbury - Present address: Department of Zoology, Oxford University, Oxford, OXI 3PS, United Kingdom

\section{Abstract}

The grazing response of ewe hoggets offered tall fescue, endophyte-infected (+E) or endophyte-free (-E) perennial ryegrass all sown with white clover into a fertile silt loam was examined in April 1990. In a second experiment 2 grazings were observed where 5 grasses had been overdrilled into old lucerne growing on stony infertile land. Pregnant ewes (August) and ewes with young lambs (October) grazed 3 replicates of tall fescue, + E perennial ryegrass, cocksfoot, phalaris and prairie grass. After the August grazing nitrogen fertiliser was applied at 0 and $300 \mathrm{~kg} \mathrm{~N} /$ ha to $5 \mathrm{x}$ $2 \mathrm{~m}$ subplots in each $30 \times 9 \mathrm{~m}$ grass plot. April observations showed that on day one $76 \%$ of grazing time was on tall fescue. During the first 4 days of grazing grass leaf height decreased 60 $\mathrm{mm}$ in tall fescue, $43 \mathrm{~mm}$ in $+\mathrm{E}$ and $42 \mathrm{~mm}$ in $-\mathrm{E}$ ryegrass while in the last 5 days decreases were 5 , 3 and $25 \mathrm{~mm}$. Over the 9 days' grazing, pseudostem height declined 5.2, 1.5 and $5.0 \mathrm{~mm}$, green grass cover from 62 to 30,65 to 44 , and 68 to $33 \%$, and herbage removal was 940,1100 and $1300 \mathrm{~kg} \mathrm{DM} /$ ha from tall fescue, $+E$ and $-E$ ryegrasses. During the first 3 days of the August grazing, grass leaf heights of cocksfoot and $+E$ ryegrass declined at a much slower rate than in the other 3 species. The October grazing showed a similar defoliation pattern on plots without N. Addition of $300 \mathrm{~kg} \mathrm{~N} /$ ha resulted in very rapid defoliation of all 5 species during the first day of the 7-day grazing period. April grazing showed that initially sheep preferred tall fescue. Even though grazing time was similar for $+E$ and $-E$ ryegrasses the hoggets consumed less $+\mathrm{E}$ than $-\mathrm{E}$ ryegrass, possibly owing to reluctance to penetrate the $+E$ pseudostem horizon. The August and October grazings demonstrated the ability of sheep to discriminate between grass species and strong rejection of cocksfoot and $+E$ ryegrass. However, $\mathrm{N}$ at a rate similar to a urine patch produced leaf in all species which was equally attractive to sheep. The reduced intake of $+E$ ryegrass measured in the April grazing may explain some of the lower animal performance of sheep on $+\mathrm{E}$ ryegrass pastures. Equally, grazing preference shown by rate of canopy height decline in any pasture is probably highly correlated with pasture intake and animal productivity.

Keywords: Acremonium lolii, Bromus willdenowii, Dactylis glomerata, Festuca arundinacea, Lolium perenne, nitrogen-fertilised pasture, Phalaris aquatica, sheep grazing preference

\section{Introduction}

A knowledge of the preferences of grazing animals for pasture species will be useful to grazing managers wishing to influence animal intake and performance.

The presence of the endophyte Acremonium coenophialum in tall fescue influences grazing behaviour of steers. Seman et al. (1990) and Stuedemann et al. (1989) showed that steers grazing endophyte-infected tall fescue spent less time grazing and had lower intakes than steers grazing endophyte-free tall fescue.

The presence of the endophyte Acremonium lolii in perennial ryegrass results in low liveweight gains in sheep (Fletcher 1982, 1983, 1985). Observation suggests this may be caused by reduced pasture intakes because of the tendency for sheep to reject endophyte-infected ryegrass, which is often dominant in New Zealand pastures. However, little is known about the effect of $A$. lolii on grazing behaviour apart from the work of Hunt \& Hay (1990). They showed that red deer hinds exhibited low grazing preference for both high- and low-endophyte perennial ryegrass, calves preferred low endophyte to high and horses high endophyte to low.

Hunt \& Hay (1990) included a wide range of grasses, legumes and herbs in their experiments and showed that hinds preferred legumes and herbs while dairy calves preferred grasses. Results for sheep preference were not presented.

Keogh (1986) found that stock select urine patches in preference to inter-urine patches. Under continuous grazing this was expressed as a higher intensity and greater frequency of defoliation of urine patches.

This paper describes observations of 3 grazing periods on 2 contrasting sites, using simple techniques such as decline in grass canopy height, to determine the ability of sheep to distinguish between grass species, 
presence or absence of endophyte in ryegrass and high and low leaf nitrogen content.

\section{Materials and methods}

\section{Experiment 1}

Two small paddocks ( 0.22 ha) each contained 3 replicates of 3 pasture treatments with the 9 plots (35 $\mathrm{x} 7 \mathrm{~m}$ ) randomly arranged. Plots were sown into a fertile silt loam in September 1989. The pasture treatments were Grasslands Roa tall fescue (Festuca arundinacea L.), endophyte (Acremonium lolii)infected (+E) Grasslands Nui perennial ryegrass (Lolium perenne L.) and endophyte-free (-E) Nui perennial ryegrass, all sown with Grasslands Pitau white clover (Trifolium repens L.). The percentage of infected tillers in the $+E$ ryegrass was $40 \%$ and the other two grasses had no endophyte. Pastures were grass dominant when the April grazing started. White clover stolons were found mainly between the grass rows $(15 \mathrm{~cm}$ spacing).

After a grazing in mid March 1990 the plots were spelled for 14 days. Flocks of 15 Romney ewe hoggets (mean liveweight $25 \mathrm{~kg}$ ) were then allocated to each paddock and grazing responses were observed from 3 to 12 April. The number of ewe hoggets grazing each plot was recorded from a $5 \mathrm{~m}$ tower located between the two blocks. Visual observations were made at 2minute intervals for 1 hour between 8:00 and 10:00 on days $1,2,3,4,5,7$ and 10. Sheep were recorded as grazing if the head jerk associated with herbage severance was observed. Grass leaf heights were measured at 10 positions per plot on days $1,3,5,7$ and 10 using a swardstick (Barthram 1986). The heights of 40 grass and white clover leaves were also measured from ungrazed swards in cages located on one plot per treatment. Grazed sward leaf heights were then corrected for current growth. Pre- and post-grazing pasture mass was measured by cutting two $0.1 \mathrm{~m}^{2}$ quadrats per plot to ground level. Sward composition was assessed by point analysis (100 first hits per plot). Pseudostem height was measured on 30 randomly selected tillers cut to ground level from each plot. Pseudostem height was defined as the distance from the base of the tiller to the top of the leaf sheath of the most recently emerged leaf. Where leaf sheaths had been defoliated, pseudostem was defined as the distance from the base of the tiller to the point of defoliation.

\section{Experiment 2}

An old, runout luceme pasture on shallow, stony silt loam was overdrilled with 4 replicates of 7 pasture species in September 1989. Plots $(30 \times 9$ m) occupied about 1 ha of the 2.5 ha paddock. Grazing behaviour on
3 replicates of 5 treatments was observed twice in 1992. The treatments were: Grasslands Wana cocksfoot (Dactylis glomerata L.), Roa tall fescue, Grasslands Matua prairie grass (Bromus willdenowii Kunth), Grasslands Maru phalaris (Phalaris aquatica L.) and Yatsyn perennial ryegrass with $100 \%$ endophyte infection. Treatment swards were typical of low fertility dryland pastures on stony soils with low tiller populations resulting in low pasture densities.

The first grazing period (100 pregnant Borderdale ewes) was from 30 July to 6 August. The area had been grazed hard in late May and the pasture mass was approximately $1000 \mathrm{~kg} \mathrm{DM} / \mathrm{ha}$ at the end of July. Heights of leaf canopies and pseudostems were measured from 20 random positions in each plot before the start of grazing and during the grazing period.

The second 7-day grazing used 130 Borderdale ewes with 200 young lambs at foot. Regrowth from 6 August was offered to the ewes and lambs from 30 September to 7 October. A second factor was introduced after the first grazing by applying nitrogen fertiliser (calcium ammonium nitrate) at zero or 300 $\mathrm{kg} \mathrm{N} / \mathrm{ha}$ to $5 \times 2 \mathrm{~m}$ subplots in each $30 \mathrm{x} 9 \mathrm{~m}$ grass plot on 21 August. Pasture mass was measured pre and post grazing. The mean mass on 30 September of the zero $\mathrm{N}$ subplots was $700 \mathrm{~kg} \mathrm{DM} / \mathrm{ha}$ while the $300 \mathrm{~kg}$ $\mathrm{N} / \mathrm{ha}$ subplots had about $1400 \mathrm{~kg} \mathrm{DM} / \mathrm{ha}$ on offer to the sheep

\section{Results}

\section{Experiment 1}

On the first day of the 9-day grazing period more ewe hoggets grazed tall fescue $(76 \%)$ than $+\mathrm{E}(12 \%)$ and $-\mathrm{E}$ ryegrass $(12 \%)$. The proportion of sheep grazing each pasture did not differ after the first day.

Leaf height was similar for all three grasses at the start of grazing (Figure 1). By day 2, tall fescue leaf height had been reduced $43 \mathrm{~mm}$ compared with only $16 \mathrm{~mm}$ in the ryegrasses. During the last 5 days of the grazing period the $-E$ ryegrass height was grazed down $25 \mathrm{~mm}$ while the tall fescue and $+E$ ryegrass were reduced by only 5 and $3 \mathrm{~mm}$. Pseudostem heights in the ryegrasses were greater than tall fescue before grazing (Table 1). Pseudostem height decreased more in tall fescue $(5.2 \mathrm{~mm})$ and $-E$ ryegrass $(5.0 \mathrm{~mm})$ than $+E$ ryegrass $(1.5 \mathrm{~mm})$ during the grazing period. Tall fescue had a lower pre-grazing pasture mass than the ryegrasses (Table 1). During grazing the $1300 \mathrm{~kg}$ $\mathrm{DM} / \mathrm{ha}$ reduction in $-\mathrm{E}$ ryegrass was greater than the 940 and $1100 \mathrm{~kg} \mathbf{D M} / \mathrm{ha}$ reductions in tall fescue and $+\mathrm{E}$ ryegrass. The $+\mathrm{E}$ ryegrass had the greatest postgrazing pasture mass. 
Table 1 Pre-and post-grazing pasture mass (kg DM/ha) and pseudostem height (nun) of each pasture treatment for April grazing.

\begin{tabular}{lcc}
\hline & Pre-grazing & Post-grazing \\
\hline Pasture Mass (kg DM/ha) & & \\
tall fescue & 1820 & $\mathbf{8 8 0}$ \\
+E ryegrass & $\mathbf{2 3 6 0}$ & 1260 \\
-E ryegrass & $\mathbf{2 3 0 0}$ & $\mathbf{1 0 0 0}$ \\
significance & $\mathbf{3 9 3}$ & \\
Isd 0.05 & & 242 \\
Pseudostem height (mm) & 32.5 & \\
tall fescue & 30.5 & 27.3 \\
+E ryegrass & 37.0 & 37.0 \\
-E ryegrass & $\mathbf{3}$ & 32.0 \\
significance & 4.2 & 4.6 \\
Isd & & \\
\hline . & & \\
\hline
\end{tabular}

At the start of grazing all treatments had similar green grass and white clover cover but tall fescue had less dead material and more bare ground than the ryegrass treatments. From day 1 to 2 the green grass cover decreased more in tall fescue (14.9\% units) than $-\mathrm{E}$ ryegrass $(4.5 \%)$ and $+\mathrm{E}$ ryegrass $(1.1 \%)$, but by day 4 all pasture treatments had about $45 \%$ green grass cover. Over the last $\mathbf{5}$ days green grass percentage decreased by over $13 \%$ in both tall fescue and $-E$ ryegrass but only $1.2 \%$ in $+E$ ryegrass. White clover cover in all treatments was low and differences between treatments were small. The bare ground increased $31.6 \%$ units during grazing in tall fescue but only $4.6 \%$ in $+\mathrm{E}$ and $6 \%$ in -E ryegrass. Dead material increased $22.9 \%$ units and $28.5 \%$ in $+\mathrm{E}$ and -E ryegrass but only $6.6 \%$ in tall fescue.

\section{Experiment 2}

Pregnant ewes showed a strong initial preference for prairie grass, phalaris and tall fescue. Grass leaf heights of $+E$ ryegrass and cocksfoot declined slowly compared with the preferred grasses (Figure 2).

Lacting ewes in early October initially preferred phalaris and tall fescue (Figure 3). After 2 days prairie grass was also defoliated rapidly. Cocksfoot and +E ryegrass were again least preferred. The addition of $300 \mathrm{~kg} / \mathrm{ha}$ of $\mathrm{N}$ resulted in all grasses being defoliated rapidly during the first day (Figure 4). Height reductions were small in all species during the final 6 days of grazing. Pasture heights of perennial ryegrass and Wana cocksfoot were, however, twice those of tall fescue and phalaris on day 7 in both $\mathrm{N}$ treatments (Figures 3 and 4). Mean $\mathrm{N}$ content of grasses on offer to the ewes was $3.4 \%$ without $\mathrm{N}$ and $4.8 \%$ in the $300 \mathrm{~kg} \mathrm{~N} / \mathrm{ha}$ treatments (Table 2).
Figure 1 Decline in grass leaf height during 3 to 12 April grazing of tall fescue $(\mathbf{O}),+E$ ryegrass $(\boldsymbol{A})$ and $-E$ ryegrass (ם). Bars indicate SE mean.

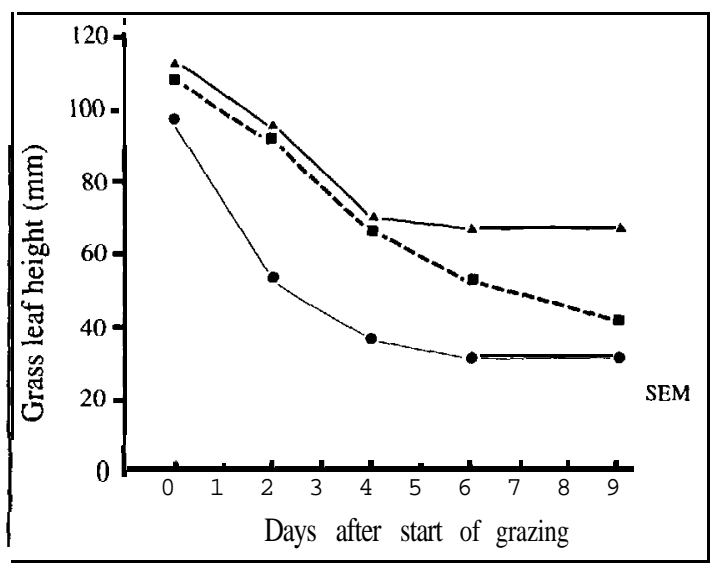

Figure 2 Decline in grass leaf height during 30 July to 6 August grazing.

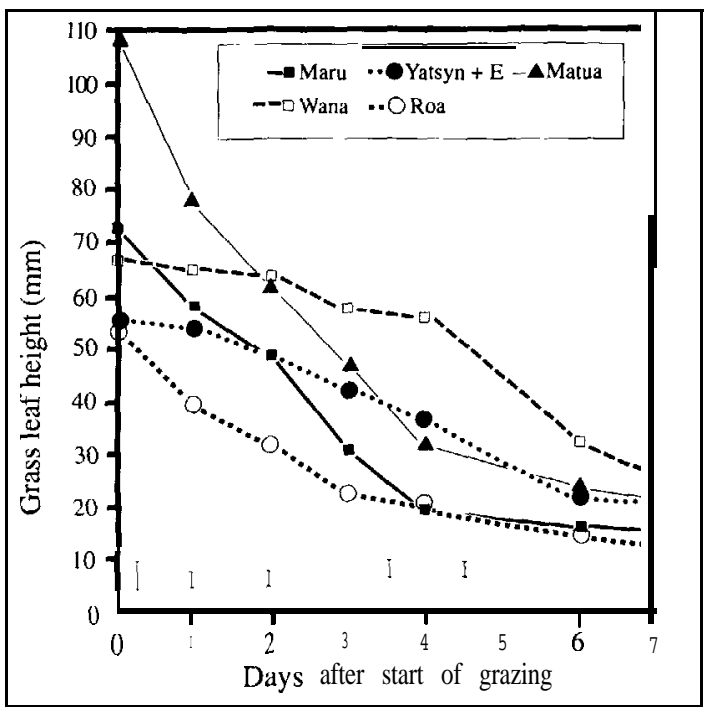

Table 2 Nitrogen content of grasses on 30 September before the October grazing.

\begin{tabular}{lcc}
\hline Species & $\begin{array}{c}\text { Percentage } \\
\text { o kgN/ha }\end{array}$ & $\begin{array}{c}\text { nitrogen } \\
300 \mathbf{~ k g N / h a}\end{array}$ \\
\hline Y atsyn & $\mathbf{2 . 8 0}$ & 4.90 \\
Matua & 3.63 & 4.59 \\
Roe & 3.53 & 4.40 \\
Wana & 3.66 & 5.10 \\
Maru & 3.52 & 5.09 \\
SEM & 0.27 & 0.27
\end{tabular}


Figure 3 Decline in grass leaf height during 30 September to 7 October grazing in zero nitrogen sub-plots.

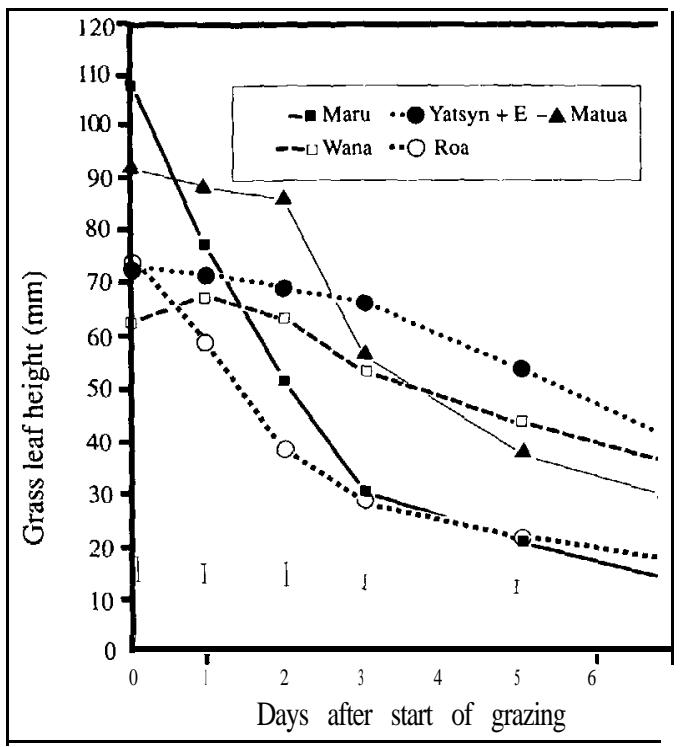

\section{Discussion}

Diet selection by grazing animals is a dynamic process during which the relative attractiveness of sward components changes. Strong preferences were initially shown for Roa tall fescue, Maru phalaris and in the August grazing for Matua prairie grass. After the most accessible green leaf of the preferred species had been grazed the sheep grazed the less attractive species more intensively (Figures 1, 2 and 3).

In experiment 1 , the greater reduction in tall fescue grass leaf canopy height was supported by the overwhelming (76\%) number of sheep grazing Roa tall fescue during the first day. Even though the leaf height of tall fescue was lower than that of the ryegrasses at the start of the grazing period the grass leaf height and percentage green grass declined more in the tall fescue over the first 2 days than in either of the ryegrass treatments. The lower number of ewe hoggets grazing tall fescue after the first day of grazing reflected the reduced opportunity to select tall fescue leaf.

The number of sheep grazing $+E$ and $-E$ ryegrass did not differ but pasture measurements indicated differences in the way sheep grazed each treatment. After day 4 leaf height and percentage green leaf cover continued to decline only in -E ryegrass. Pseudostem height decreased $5 \mathrm{~mm}$ in $-\mathrm{E}$ but only $1.5 \mathrm{~mm}$ in $+\mathrm{E}$ ryegrass. Consequently, $200 \mathrm{~kg} \mathrm{DM} / \mathrm{ha}$ more was removed from $-E$ than $+E$ ryegrass. Although penetration into the pseudostem horizon was minimal in all pasture
Figure 4 Decline in grass leaf height during 30 September to 7 October grazing in $300 \mathrm{~kg}$ Nha sub-plots.

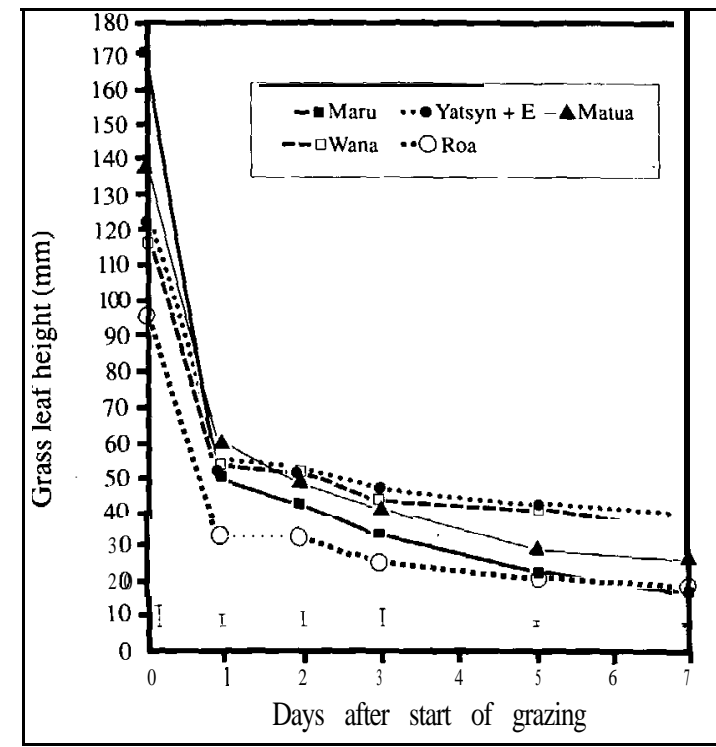

treatments, supporting the 'pseudostem barrier' concept of Barthram (1980), pasture measurements suggest that ewe hoggets were more reluctant to graze into the pseudostem horizon of $+E$ than -E ryegrass. In support of this, Edwards (1990) found that while the short-term intake rate by sheep of $+E$ and $-E$ ryegrass leaf samples was similar, the short-term intake rate of $+E$ pseudostems was less than that of -E ryegrass pseudostems. It was unfortunate that the $+E$ ryegrass in Experiment 1 had only $40 \%$ endophyte infection. Differences between $+\mathrm{E}$ and -E ryegrass treatments would very likely have been greater if the $+\mathrm{E}$ sward had been $100 \%$ endophyte infected. Edwards (1990) measured greater variance in grass leaf height during grazing in $+E$ than $-E$ ryegrass, which suggests that the hoggets were selecting-E ryegrass from the $40 \%$ infected sward. This would also help explain the lower apparent intake on the $+\mathrm{E}$ ryegrass. Further observations (Edwards 1990) in spring on a lower fertility site showed endophyte incidence in intensely grazed areas was $30 \%$ but in laxly grazed areas was $70 \%$.

The preference of ewes for tall fescue and phalaris in the August and October grazings appears to be partly related to those grasses having more palatable pseudostems. Their final heights were lower at the end of both grazing periods. The ewes were able to discriminate strongly among the five grass species and found the unfertilised green leaf of Wana cocksfoot $(3.7 \% \mathrm{~N})$ and Yatsyn $+\mathrm{E}$ ryegrass $(2.8 \% \mathrm{~N})$ least attractive. When $\mathrm{N}$ fertiliser was applied at a rate 
equivalent to a weak urine patch the Wana $(5.1 \% \mathrm{~N})$ and Yatsyn $(5.0 \% \mathrm{~N})$ became much more attractive and the ewes showed a very strong preference for all $\mathrm{N}$ treated grasses on the first day of grazing. These observations were expected, given the preference for mine patches described by Keogh (1986).

\section{Conclusion}

Grazing sheep can distinguish between grass species, the presence or absence of endophye in ryegrass, the level of nitrogen in grass leaves and distinguish leaf from pseudostem. Grazing managers with a knowledge of animal grazing preference may therefore exercise some control over pasture intakes and animal performance.

\section{ACKNOW LEDGEMENTS}

The authors thank Mr D.B. Pownall for technical assistance.

\section{REFERENCES}

Barthram, G.T. 1986. Experimental techniques: the HFRO sward stick, The Hill Farming Research Organisation Biennial Report 1984-85. pp 29-30.

Barthram, G.T. 1980. Sward structure and depth of the grazed horizon. Grass and forage science 36: 130131.

Edwards, G.R. 1990. Influence of the endophyte fungus in ryegrass on grazing preference by sheep. BAgrSc Honours dissertation, Lincoln University.

Fletcher, L.R. 1982. Observations of ryegrass staggers in weaned Jambs grazing different ryegrass pastures. New Zealand journal of experimental agriculture 10: 203-207.
Fletcher, L.R. 1983. Effects of presence of Lolium endophyte on growth rates of weaned lambs, growing on to hoggets on various ryegrasses. Proceedings of the New Zealand Grassland Association 44: 207-237.

Fletcher, L.R. 1985. Lolium endophyte and sheep performance on perennial ryegrass cultivars. Proceedings of the New Zealand Grassland Association 47: 99-105.

Hunt, W.F.; Hay, J.M. 1990. A photographic technique for assessing the pasture species performance of grazing animals. Proceedings of the New Zealand Grassland Association 51: 191-196.

Johnson, M.R. 1992. Grazing preference for pasture species by sheep. BAgrSc Honours dissertation, Lincoln University.

Keogh, R.G. 1986. Fungal distribution and livestock defoliation patterns in pasture ecosystems, and the development and control of dietary-dependent disorders. Proceedings of the New Zealand Grassland Association 45: 93-98.

Seman, D.H.; Stuedemann, J.A.; Breedlove, D.L.; Wilkinson, S.R.; Belesky, D.P.; Thompson, F.N.; Stewart, F.P. 1990. Differences in grazing behaviour of steers consuming endophyte infected on noninfected tall fescue. Proceedings of International Symposium on Acremonium/Grass Interactions: 267-272.

Stuedemann, J.A.; Breedlove, D.L.; Pond, K.R.; Belesky, D.D.; Tate, L.P.; Thompson, F.N.; Wilkinson, S.R. 1989. Effect of endophyte (Acremonium coenophialum) infection of tall fescue and paddock exhange on intake and performance of grazing steers. Proceedings of the XVI International Grassland Congress: 1243- 1244. 